\title{
Semi-Automatic Fracture Mapping Using Cellular Neural Networks Applied to ALOS PALSAR 2 Images of the Western Highlands of Cameroon
}

\author{
Valère-Carin Jofack Sokeng1,2, Benjamin N'gounou Ngatcha3 ${ }^{3}$, Fernand Koffi Kouame1,2, \\ Jean Homian Danumah², Lucette Akpa You ${ }^{2}$ \\ ${ }^{1}$ Unité de Recherche et d'Expertise Numérique, Université Virtuelle de Côte d'Ivoire, Abidjan, Côte d'Ivoire \\ ${ }^{2}$ Centre Universitaire de Recherche et d'Application en Télédétection, Abidjan, Côte d’Ivoire \\ ${ }^{3}$ Laboratoire Mixte International en Sciences de l'Eau (LAMISE), Université de Ngaoundéré, Ngaoundéré, Cameroun \\ Email: valere.jofack@uvci.edu.ci
}

How to cite this paper: Jofack Sokeng, V.-C., N'gounou Ngatcha, B., Kouame, F.K., Danumah, J.H. and You, L.A. (2021) Semi-Automatic Fracture Mapping Using Cellular Neural Networks Applied to ALOS PALSAR 2 Images of the Western Highlands of Cameroon. International Journal of Geosciences, 12, 1055-1069.

https://doi.org/10.4236/ijg.2021.1211056

Received: October 20, 2021

Accepted: November 27, 2021

Published: November 30, 2021

Copyright $\odot 2021$ by author(s) and Scientific Research Publishing Inc. This work is licensed under the Creative Commons Attribution International License (CC BY 4.0).

http://creativecommons.org/licenses/by/4.0/

\begin{abstract}
In Cameroon in general and in the Highlands of Cameroon in particular, there is no fracture map since its realization is not easy. The region's harsh accessibility and climatic conditions make it difficult to carry out geological prospecting field missions that require large investments. This study proposes a semi-automatic lineament mapping approach to facilitate the elaboration of the fracture map in the West Cameroon Highlands. It uses neural networks in tandem with PCI Geomatica's LINE algorithm to extract lineaments semi-automatically from an ALOS PALSAR 2 radar image. The cellular neural network algorithm of Lepage et al (2000) is implemented to enhance the pre-processed radar image. Then, the LINE module of Geomatica is applied to the enhanced image for the automatic extraction of lineaments. Finally, a control and a validation of the expert by spatial analysis allows elaborating the fracture map. The results obtained show that neural networks enhance and facilitate the identification of lineaments on the image. The resulting map contains more than 1800 fractures with major directions $\mathrm{N} 20^{\circ}-30^{\circ}$, NS, $\mathrm{N} 10^{\circ}-20^{\circ}, \mathrm{N} 50^{\circ}-60^{\circ}, \mathrm{N} 70^{\circ}-80^{\circ}, \mathrm{N} 80^{\circ}-90^{\circ}, \mathrm{N} 100^{\circ}-110^{\circ}, \mathrm{N} 110^{\circ}-120^{\circ}$ and $\mathrm{N} 130^{\circ}-140^{\circ}$ and $\mathrm{N} 140^{\circ}-150^{\circ}$. It can be very useful for geological and hydrogeological studies, and especially to inform on the productivity of aquifers in this region of high agro-pastoral and mining interest for Cameroon and the Central African sub-region.
\end{abstract}

\section{Keywords}

Fracture Map, Lineament Mapping, Cellular Neural Networks, Highlands of 


\section{Introduction}

Fracture mapping is very important in mining and hydrogeological prospecting. Indeed, fractures promote the circulation of water and facilitate the location of favorable targets for mineralization exploration. In mining prospecting, a hierarchical mapping of fractures allows to orientate the prospecting during the reconnaissance phase and to bring new ideas on potential traps. In hydrogeology and hydrology, they are the origin of the formation of underground water tables and constitute the zones par excellence of water flow.

In the Western Cameroon Highlands in general, geological maps date from the colonial period [1] [2] [3]. Since then, the identification of fractures from field missions has been limited by the difficulty of access to the region. The main obstacles are generally the large area to cover and other natural factors (rivers, mountains, dense woodlands) that make this approach expensive and time consuming for the state of Cameroon.

Satellite images, with the synoptic view they offer, have proven to be complementary to this difficult work and have made it possible to develop several methods for direct and indirect study of fractures [4]. Indeed, in an image, fractures correspond to rectilinear or curvilinear features that can be perceived on the surface of the Earth's crust and that reflect the presence of deeper phenomena (faults, seams, and geological contacts), generally known by the name of lineaments [5]. The identification of lineaments in satellite images is therefore dependent on the ability of the sensor to detect the slight variations in reflectance associated with these geological phenomena [6].

Several studies in Cameroon [4] [7]-[12] and Central Africa [13] [14] have used satellite imagery to detect lineaments. In the West Cameroon Highlands, a region with high agricultural and agro-pastoral potential and with very rugged terrain and complex geomorphology, only the work of [11] focuses on structural mapping by remote sensing. This work, which is limited to the characterization of the large collapse structures of Ndop, Mapé and Batié, has shown that remote sensing is an irreplaceable source of geomorphology [11]. The lineament extraction approaches frequently used are of two types [15]: 1) the manual approach which is done by photo-interpretation of processed images on one hand; and 2) the automatic extraction approach [16] [17] [18] [19] [20]. The manual technique, which is done by photo-interpretation, is very slow, laborious and often gives subjective results. As for the second approach, which is hardly used in structural studies by remote sensing in Cameroon, it has the disadvantage of presenting the lineaments as small strands. Indeed, during extraction, the lineaments of regional scope are intersected by occlusions [21] due to the relief, the presence of trees and buildings that give them a discontinuous appearance. 
The main objective of this study is to extract fractures from ALOS PALSAR 2 images of the Western Highlands of Cameroon. This study proposes a semiautomated lineament mapping approach to facilitate fractures mapping in the West Cameroon Highlands. It uses neural networks [21] [22] [23] in tandem with PCI Geomatica's LINE algorithm to semi-automatically extract lineaments from ALOS PALSAR 2 satellite imagery while respecting their spatial continuity and the regional extent of fractures.

\section{Study Area}

\subsection{Location and Hydrogeomorphological Condition}

The study area selected in the Western Highlands of Cameroon (WHPC) has an area of $9000 \mathrm{~km}^{2}$ (Figure 1) and is located between $09^{\circ} 50^{\prime}$ and $10^{\circ} 45^{\prime}$ East longitude and $5^{\circ} 15^{\prime}$ and $6^{\circ} 10^{\prime}$ North latitude. It is partially combined with the West and North-West regions of Cameroon with Bafoussam and Bamenda as the respective headquarters and important urban centers.

The relief is mountainous (altitude above $2000 \mathrm{~m}$ ) with plains (altitude below $500 \mathrm{~m}$ ) and plateaus (altitude between 500 and $2000 \mathrm{~m}$ ) associated with plutonic massifs such as Mbam (2335 m), Nkogam (2263 m), Mbapit (1989 m), with altitudes exceeding $2000 \mathrm{~m}$. In the west, the Santa Peak or Mount Lefo $(2550 \mathrm{~m}$ ) constitutes the Bamenda Mountains. The Bamboutos Mountains, with a series of peaks above $2700 \mathrm{~m}$, are the highest point of the West Cameroon region and constitute the second largest water tower in Cameroon after Adamaoua [10]. They therefore provide the majority of the water that drains and infiltrates the region.

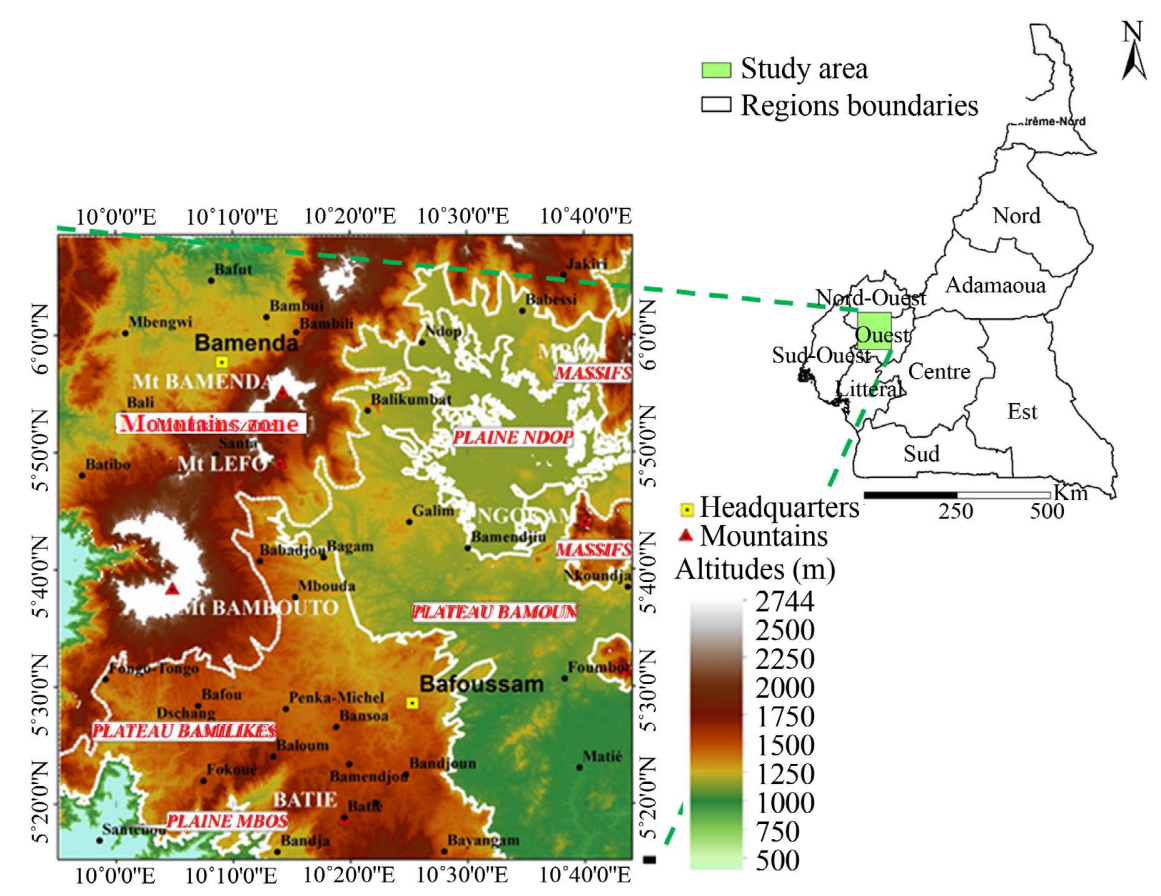

Figure 1. Location map of the study area. 
The hydrographic network of the HPOC is dense, linked to the relief [24] and follows the fracturing with a general SE-NW and SW-NE direction. It is made up of numerous rivers (Mbam, Noun, Nkam, Metchum, Menoua, etc.) and is drained by four main watersheds, two of which are of coastal origin (Cross-River and Wouri) and two of continental origin (Benue-Niger and Sanaga). The two largest water collectors in the region are the Noun and the Nkam. They are oriented NW-SE and NS and have tributaries (Mifi South, Mifi North, Menoua, etc.) that are often perpendicular to them. They are sometimes crossed by numerous waterfalls (Marnmywata, Metche, etc.) at the level of the flow fronts and feed lake dams, the most important of which is the Lake Bamendjing dam.

\subsection{Geological and Structural Framework}

The geology is very complex [10] [11]. The basement, representing about $2 / 5$ of the study area, consists of crystallophyllous rocks and magmatic rocks emplaced during the Pan-African orogeny and overlain by a layer of Cenozoic and Quaternary volcanic rocks [1] [2] (Figure 2). The crystallophyllous rocks consist of ortho-gneiss, migmatitic gneiss, and amphibolites crossed by veins [25]. The magmatic rocks are composed of ancient syn-tectonic granitic massifs (biotite granites) and post-tectonic massifs [10]. They dominate the south and north of the study area and form large plutons such as the Bandja, Fomopéa (Fokoué) and Batié plutons [25]. Volcanic formations dominate the western highlands of Cameroon and include the basaltic cover of the entire Bamilek plateau (basaltic quarries of Dschang, Bafou, Bandjoun, Bangang, Batcham and Choumi Falls, Metche...), the trachytes of the Bamboutos and Bamenda mountains and rhyolites (younger) in the Bamoun plateau.

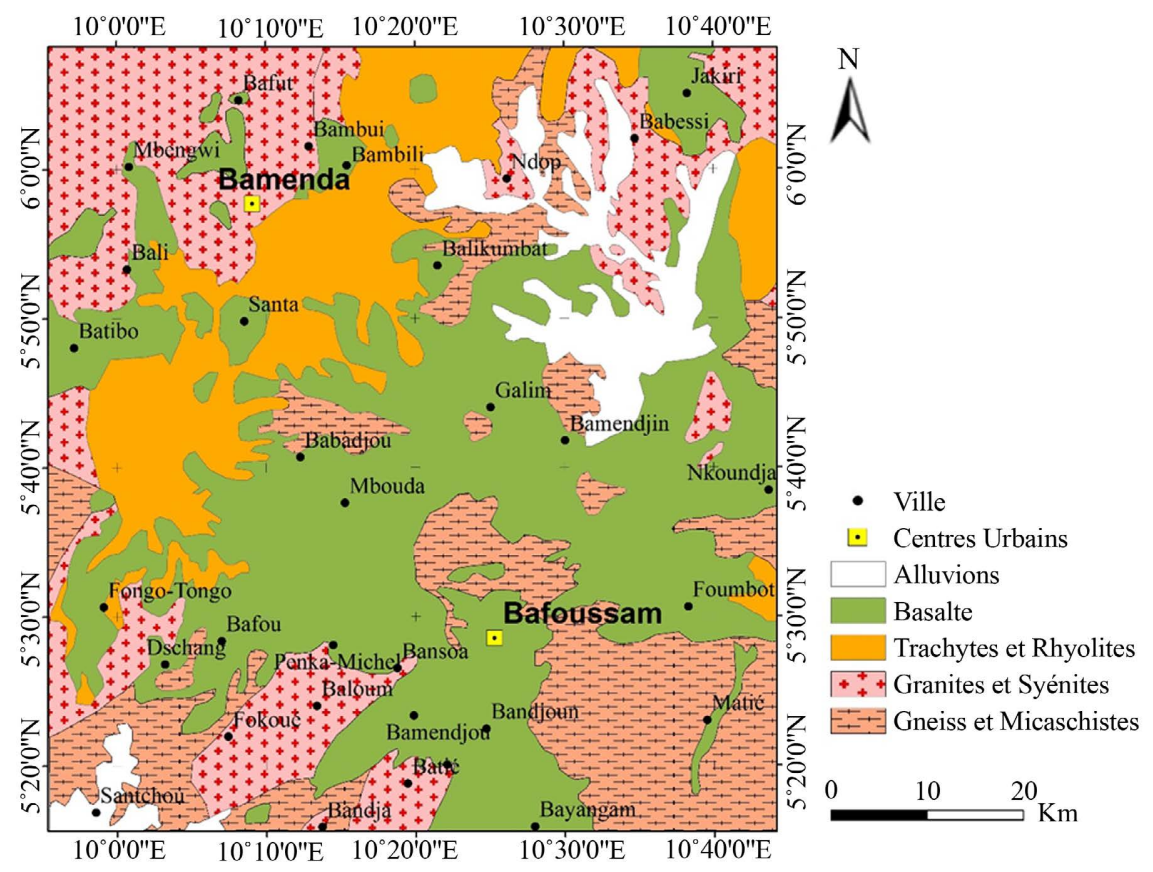

Figure 2. Geological map of the study area. 
Structurally, two tectonic phenomena have occurred in the West Cameroon Highlands that are unfortunately not represented on the existing 1:500,000 geological map: 1) Folding of crystalline rocks; 2) Brittle tectonics with large dislocations observed on crystalline and magmatic rocks. Folding is related to the first two phases of deformation defined [26] west of the Tcholliré-Banyo shear zone (North Cameroonian domain): phase D1 marked by horizontal foliation, isoclinal folds and a stretching lineation oriented $\mathrm{N} 110^{\circ} \mathrm{E}-\mathrm{N} 140^{\circ} \mathrm{E}$; and phase D2 characterized by tight folds with a vertical axial plane that carries a mineral lineation parallel to the fold axes, oriented NNE-SSW to NE-SW [27]) The main directions of foliations recorded during field missions are $\mathrm{N} 118^{\circ} \mathrm{E}, \mathrm{N} 142^{\circ} \mathrm{E}$, $\mathrm{N} 123^{\circ} \mathrm{E}, \mathrm{N} 106^{\circ} \mathrm{E}, \mathrm{N} 145^{\circ} \mathrm{E}, \mathrm{N} 125^{\circ} \mathrm{E}$, in the Dschang area, $\mathrm{N} 20^{\circ} \mathrm{E}$ to $\mathrm{N} 80^{\circ} \mathrm{E}$ north of Santchou, $\mathrm{N} 60^{\circ}-70^{\circ} \mathrm{E}$ southeast of Bafoussam. Similarly, in the gneisses and amphibolites, foliation and schistosity with isoclinal folds with axial planes oriented $\mathrm{N} 60^{\circ}-70^{\circ} \mathrm{E}$ have been identified. As for the brittle tectonics, very few signs are listed on these gneissic formations if we omit the shear planes. The mylonites are the only evidence of ancient faults with orientations that vary from $\mathrm{N} 28^{\circ} \mathrm{E}$ to $\mathrm{N} 58^{\circ} \mathrm{E}$. On the other hand, on the magmatic rocks, horizontal faults with sinister movement dominate according to the directions $\mathrm{N} 50^{\circ}-60^{\circ} \mathrm{E}$ and $\mathrm{N} 120^{\circ}-130^{\circ} \mathrm{E}$.

This lithological and structural diversity, which justifies the lack of studies of the West Cameroon Highlands, makes it difficult to store and circulate water, which is only possible if there is a sufficiently thick alteration zone and a good network of fissures or uncapped fractures. This study highlights the fracture networks of this region of high groundwater exploitation, which is of proven agropastoral and mining interest for Cameroon and the Central African sub-region.

\section{Material and Methods}

\subsection{Materials}

The Douala East [2] and Douala West [1] sheets of the 1:500,000 geological maps provided information on the geological formations and contours of the region. From the 1:200,000 topographic maps (Douala East and Douala West) of the Yaoundé IGN, the hydrographic network, roads, high voltage lines and many other anthropogenic linear structures were extracted for the validation of the lineaments. Finally, six scenes of images taken by the PALSAR sensor of the Japanese ALOS satellite acquired in November 2015 (dry season) in Dual polarization mode (HH/HV) from the project submitted to the European Space Agency (ESA) and whose number is ID 28952. The choice of these images is motivated by the high spatial resolution $(12.5 \mathrm{~m}$ ) and the high wavelength (L-band $=23.6$ $\mathrm{cm}$ ) interesting for a good structural and geological mapping.

Image pre-processing and processing were performed with PCI Geomatica. The neural networks were trained with MATLAB 2020a. Finally, the digitization, spatial analysis and the realization of the maps were carried out with ArcGIS. 
The methodological approach used can be summarized in 4 steps: first, pre-processing operations are performed on the ALOS PALSAT image; the cellular neural network algorithm [21] is trained in MATLAB [28] and applied to improve the pre-processed image; then, the LINE module of Geomatica is applied on the improved image for automatic extraction of lineaments; finally, a control and a manual validation by spatial analysis lead to the realization of the fracturing map.

\subsection{Methods}

\subsubsection{Image Pre-Processing}

The pre-processing consisted in applying on the ALOS PALSAR 2 scenes of the study area, mosaic operations and a Lee filter of size $5 \times 5$ aiming to reduce speckle and improve the readability of the image while preserving the high frequencies and the geological structures (Figure 3).

\subsubsection{Cellular Neural Network for Lineament Detection}

The detection of lineaments on an image consists in finding the local variations of gray levels. One of the simplest methods is to calculate the first derivative of the image called gradient [21]. The lineament corresponds in fact to the local maximum of the gradient, the result of this derivative. The objective of the cellular neural networks used is to calculate the gradient while enhancing the lineaments. In a dynamic of continuity, we have implemented the architecture of the directional cellular neural network with large neighborhood and formed by a large matrix of identical, homogeneous and interconnected cells proposed in previous works [21] [28] [29] and which have demonstrated their relevance to the detection of contours (Figure 4).

\subsubsection{Automatic Extraction of Lineaments}

To isolate the detected lineaments, the LINE algorithm of Geomatica [30] was applied to the enhance image. Parameters such as RADI (Filter Radius $=10$ ), GTHR (Edge Gradient Threshold = 100), FTHR (Line Fitting Threshold $=30$ ),
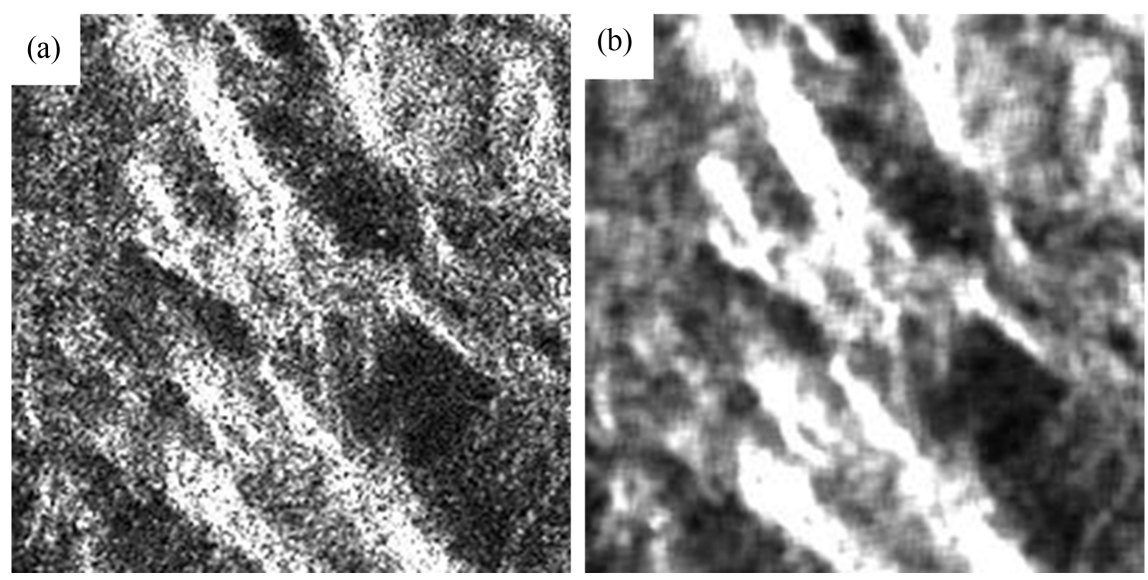

Figure 3. Raw radar image (a) and preprocessed image with Lee filter (b). 


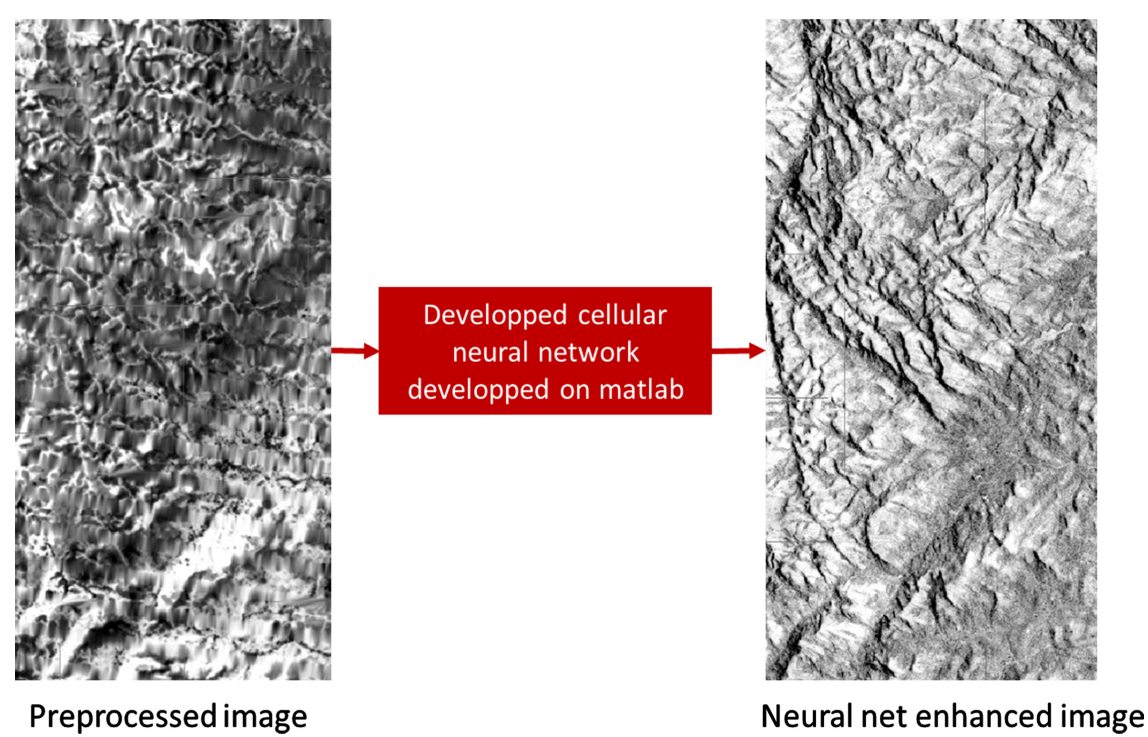

Figure 4. Application of cellular neural networks developed by on the enhanced image.

LTHR (Curve Length Threshold $=5$ ), ATHR (Angular Difference Threshold = 35) and DTHR (Linking Distance Threshold $=20$ ) were defined and the lineaments in vector format of the study area were extracted and validated and interpreted in order to deduce the fracturing map of the Western Highlands of Cameroon.

\subsubsection{Fracture Mapping and Validation}

Firstly, the validation consisted in eliminating by geoprocessing, the linear structures (roads, tracks, plantation limits, high voltage lines...) extracted by the LINE algorithm. Secondly, a multi-criteria interpretation allowed to gather information from digital terrain models, previous works and field missions to make a rigorous selection of fractures that have an appreciable length on the image, represent in several cases the alignment of water drainage and vegetation and coincide with slope breaks or drainage anomalies.

\section{Results and Discussion}

\subsection{Results}

Figure 5 presents a portion of raw ALOS PALSAR 2 image on which cellular neural networks are used. It highlights the improvement brought by this method which enhances several regional and local accidents. Specifically, the application of cellular neural networks allows us to see large gashes that were masked by vegetation on the raw image. The local cracks and fractures of the large geological formations in the study area are clearly visible and are clearly marked in Figure 5(b) and Figure 5(c).

The application of the LINE module on the enhanced image facilitates the automatic extraction of all lineaments (Figure 6) and a fracture map representing up to 1850 fractures (Figure 7). 

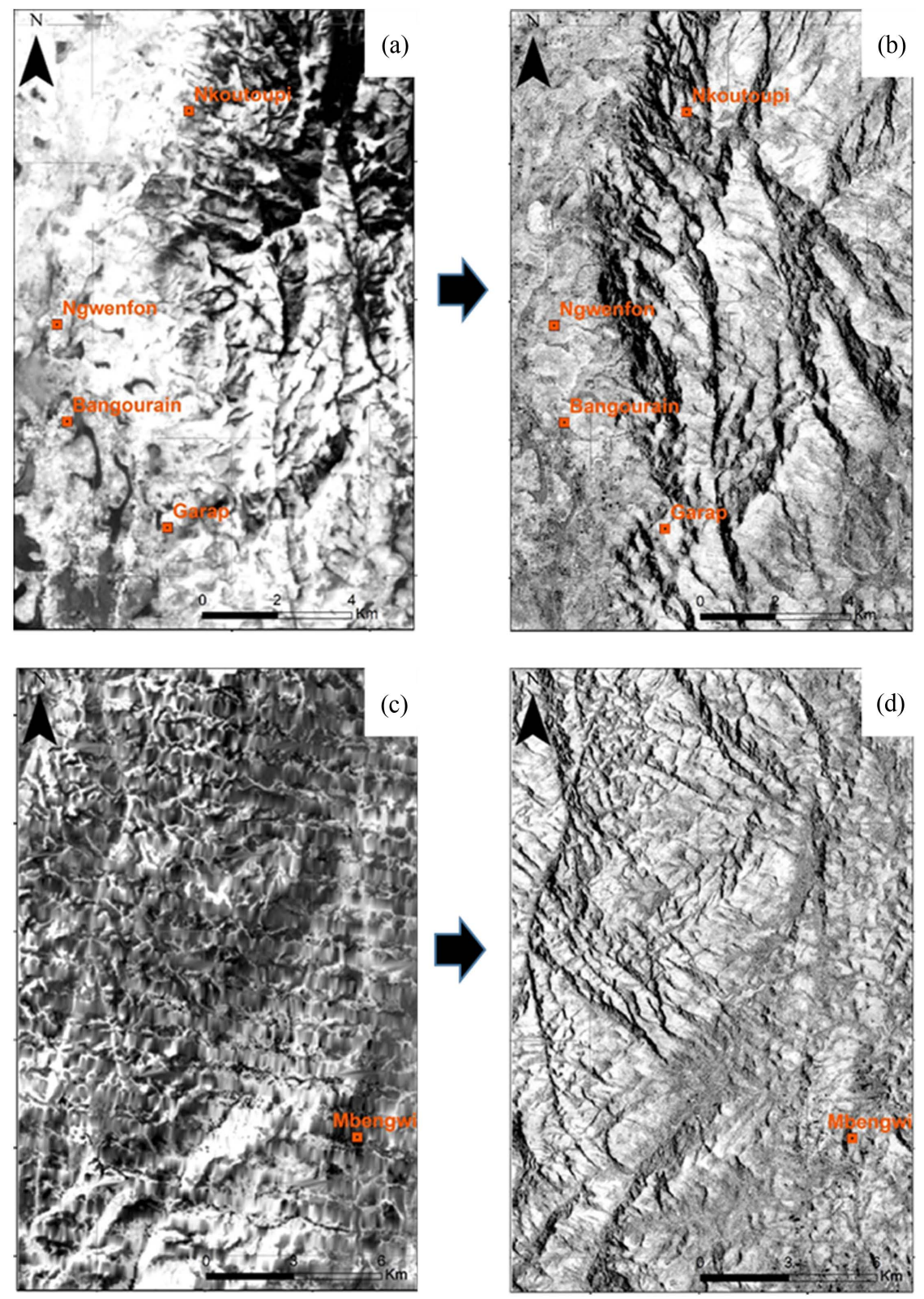

Figure 5. Regional and local accidents enhanced by cellular neural networks; ((a) and (c)) portions of granitic and rhyolitic outcrops not enhanced; ((c) and (d)) portions of granitic and rhyolitic formations enhanced by cellular neural networks.

The combination of the different results gives a fracture map that shows lineaments with different lengths and directions.

Statistical analysis of fracture directions in this area of the HPOC (Figure 8) reveals four major directions: $\mathrm{N} 50^{\circ}-60^{\circ}, \mathrm{N} 70^{\circ}-80^{\circ}, \mathrm{N} 110^{\circ}-120^{\circ}$ and $\mathrm{N} 130^{\circ}-$ $140^{\circ}$. Other secondary directions are highlighted: $\mathrm{N} 20^{\circ}-30^{\circ}$, NS, N10 $-20^{\circ}$, $\mathrm{N} 80^{\circ}-90^{\circ}, \mathrm{N} 100^{\circ}-110^{\circ}$ and $\mathrm{N} 140^{\circ}-150^{\circ}$.

On the ground, these directions correspond to the NE - SW, NW - SE and EW directions along which the valleys, hills and hydrographic network are elongated. Furthermore, they are similar to the directions of the foliation planes 

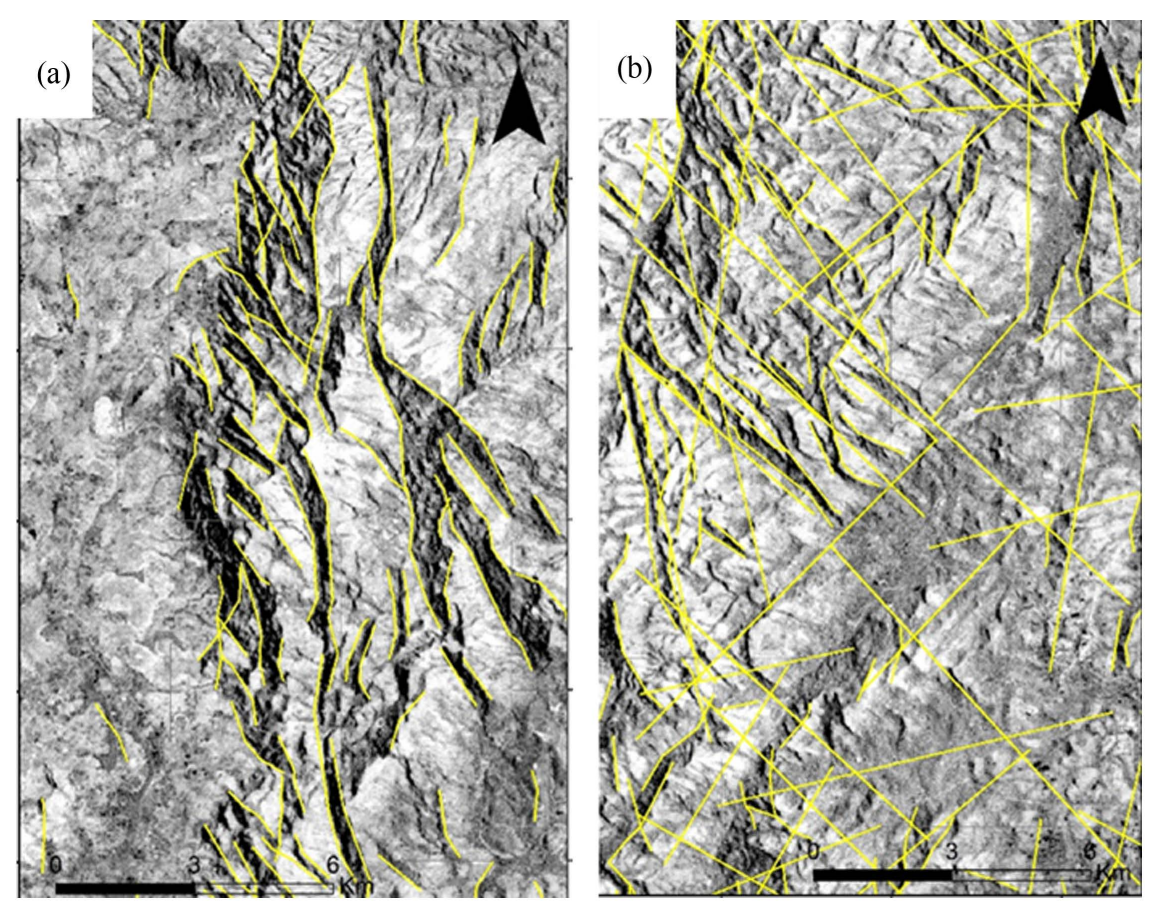

Figure 6. Lineaments extracted from neural network enhanced images on rhyolites (a) and granites (b).

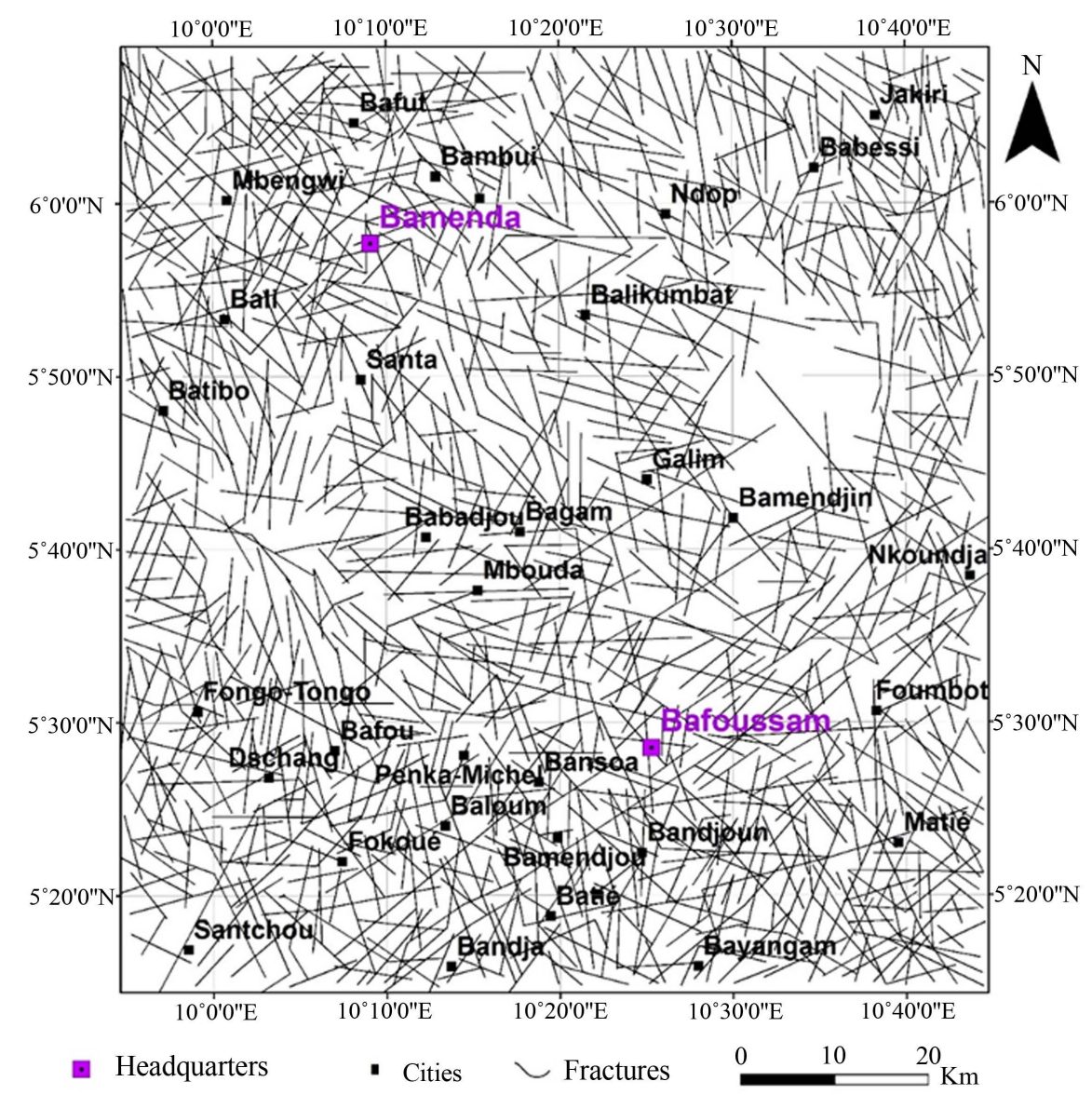

Figure 7. Fracture map of the study area. 


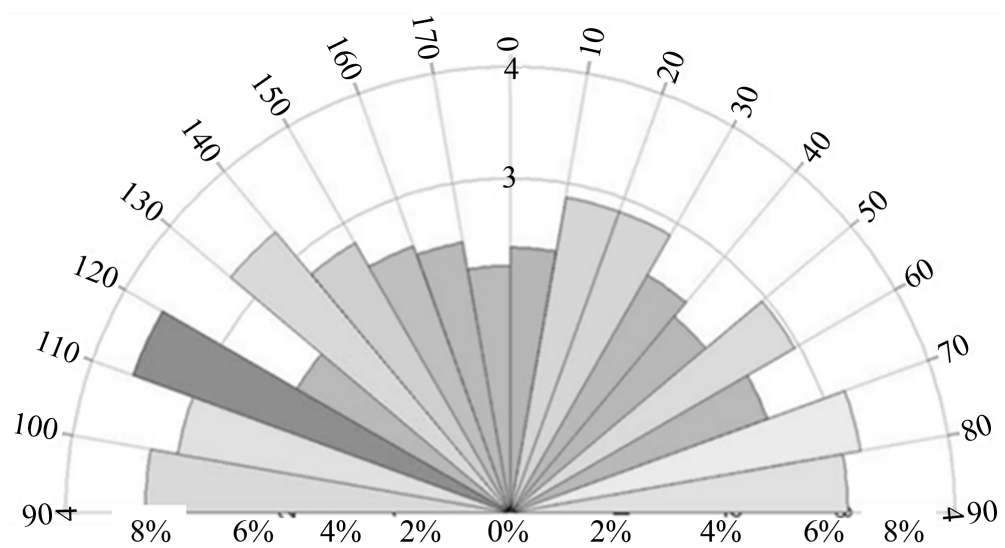

(a)

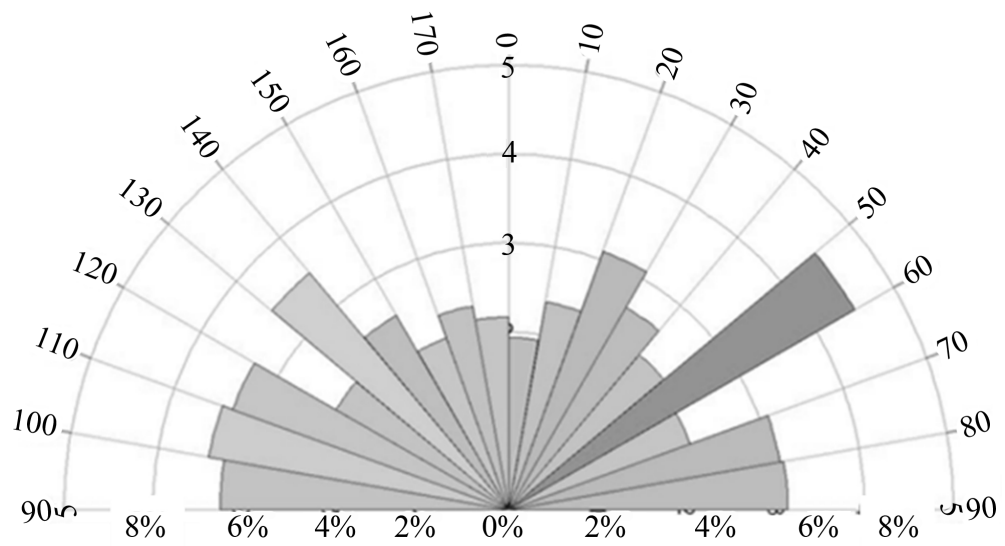

(b)

Figure 8. Directional rosettes in number (a) and cumulative lengths (b).

$\left(\mathrm{N} 25^{\circ}-75^{\circ}\right)$, schistosity $\left(\mathrm{NS}-\mathrm{N} 60^{\circ}\right)$ and diaclases $\left(\mathrm{N} 20^{\circ}-40^{\circ}\right.$ and $\mathrm{N} 120^{\circ}-$ $\left.130^{\circ}\right)$. These more intense major directions are consistent with the Cameroon Line regional faults $\left(\mathrm{N} 20^{\circ}-30^{\circ}, \mathrm{N} 70^{\circ}, \mathrm{N} 135^{\circ}\right)$ and with deformations $\left(\mathrm{N} 110^{\circ}\right.$ $\left.140^{\circ}, \mathrm{NE}-\mathrm{SW}, \mathrm{ESE}-\mathrm{NNW}, \mathrm{EW}\right)$ in the northern domain of the Pan-African Central African Range.

The distribution of the orientation of these fractures is heterogeneous over the entire study area. Indeed, the more fractured basement rocks have orientations that differ from those observed in younger rocks such as basalts, trachytes and alluvium. The gneisses are mostly oriented $\mathrm{N} 20^{\circ}-30^{\circ}, \mathrm{N} 90^{\circ}-100^{\circ}, \mathrm{N} 110^{\circ}-$ $120^{\circ}, \mathrm{N} 150^{\circ}-160^{\circ}, \mathrm{N} 160^{\circ}-170^{\circ}$ while the granites have major directions $\mathrm{N} 10^{\circ}-$ $20^{\circ}, \mathrm{N} 70^{\circ}-80^{\circ}, \mathrm{N} 130^{\circ}-140^{\circ}, \mathrm{N} 140^{\circ}-150^{\circ}$ and $\mathrm{N} 160^{\circ}-170^{\circ}$. The high fracture density observed in these formations and the diversity of directions, can be explained by the fact that these basement rocks have undergone tectonic movements originating from both the Pan-African orogeny and those related to the Cameroon line. On the other hand, the younger rocks, essentially related to the Cameroon Line tectonics, are the least fractured and follow only the NS, N50 $60^{\circ}$ and $\mathrm{N} 100^{\circ}-110^{\circ}$ directions. All these faults are therefore points of weakness for groundwater and are of great interest for the productivity of drilling in the Western Highlands of Cameroon. 
Areas of high and very high density occupy more than half of the study area. These areas dominate the south and northwest. An area of high density appears in the northeast on the density map by number, while it seems to disappear on the map by cumulative length. In general, the low-density zones are located at the limits of the study area and around the alluvial plains where drainage is intense. Finally, from a geological point of view, the high fracture densities dominate the basement zones and thus allow a better knowledge of the geometry of the aquifers in the study area.

\subsection{Discussion}

Cellular neural networks have facilitated the analysis of the images by enhancing the lineaments. This method is characterized by its speed of execution in the extraction; thus reducing the time put in the realization of the structural map. The results obtained are consistent with previous works [21] [23] [28] [29] using neural network techniques to extract lineaments automatically on a satellite image. They eliminate the effects of landforms and vegetation on the spatial continuity of structures in HPOCs. However, their main limitation is the significant number of parameters to be considered in the extraction that can lead, depending on the expert, to a variation of the fracturing map. Finally, the extracted lineaments require a thorough validation, because the applied method considers as lineament, any linear discontinuity whatever its origin. However, the results obtained are fast and considerably reduce the expert's time for the study of fracturing in this very rugged and difficult to access region.

The use of ALOS PALSAR radar imagery is only one of a multitude of applications of remote sensing in geology [4] [6] [8] [11] [13] [14] [19]. The synoptic view it provides facilitates landscape analysis, and discrimination of geological structures including fractures not present on previous geological maps [1] [2]. Several kilometer-long fractures could be mapped and the fracture density of the region was highlighted.

The frequency of lineaments and their importance in cumulative length are close to the major directions (N-S, N70 ${ }^{\circ} \mathrm{E}, \mathrm{E}-\mathrm{W}$ and $\mathrm{N} 135^{\circ} \mathrm{E}$ ) noted in previous studies in the region [10] [11] [25] and which explain the tectonics of the Cameroon Line [25] [26] [27]. Tectonic faults oriented $\mathrm{N} 20^{\circ}-30^{\circ}, \mathrm{N} 50^{\circ}-60^{\circ}$, $\mathrm{N} 70^{\circ}-80^{\circ}, \mathrm{N} 110^{\circ}-120^{\circ}$ and $\mathrm{N} 130^{\circ}-140^{\circ}$, were the most frequent and prominent and are consistent with fieldwork [1] [2] [3] [9] [10] [11] [12] [25] the directions of the major regional faults namely the Cameroon Line $\left(\mathrm{N} 20^{\circ}-30^{\circ} \mathrm{E}\right)$ and the faults in the North Cameroonian domain of the Pan-African Central African chain $\left(\mathrm{N} 30^{\circ} \mathrm{E}\right.$ and $\left.\mathrm{N} 70^{\circ} \mathrm{E}\right)$ [12] [27]. These faults are points of vulnerability that water passes through during rock weathering that are of great interest for aquifer productivity in the West Cameroon Highlands.

\section{Conclusion}

This study has shown that ALOS PALSAR 2 satellite images are well suited to the 
study of fractures in the western highlands. In this region where field missions are very expensive, the semi-automatic lineament extraction approach using neural networks can be a palliative to facilitate the realization of a detailed fracture map sketch. Indeed, these networks improve the enhancement of pre-processed images and make the identification and automatic extraction of lineaments easy. The expert's intervention is only necessary for the validation of the extracted lineaments and allows to have a more or less exhaustive fracturing map. However, the number of important parameters to define for the image enhancement and for the extraction is the main difficulty in the application of this method. The algorithms of [21] and [29] work, therefore deserve to be tested in different regions of Cameroon and Africa, experimented extensively in synergy with field studies and integrated into major image processing software to facilitate the realization of geological and structural maps in Africa. The method used in this study has allowed us to identify fractures whose major directions $\left(\mathrm{N} 50^{\circ}-60^{\circ}, \mathrm{N} 70^{\circ}-80^{\circ}, \mathrm{N} 110^{\circ}-120^{\circ}\right.$ and $\mathrm{N} 130^{\circ}$ $\left.-140^{\circ}\right)$ and secondary directions $\left(\mathrm{N} 20^{\circ}-30^{\circ}\right.$, NS, N10 $-20^{\circ}, \mathrm{N} 80^{\circ}-90^{\circ}, \mathrm{N} 100^{\circ}-$ $110^{\circ}$ and $\mathrm{N} 140^{\circ}-150^{\circ}$ ) are in phase with the directions of the major regional faults of the Cameroon Line $\left(\mathrm{N} 20^{\circ}-30^{\circ} \mathrm{E}\right)$ and faults in the North Cameroonian domain of the Pan-African chain of Central Africa. The distribution of the orientation of these fractures is heterogeneous over the entire study area. The basement formations are more fractured and the average fracture density of the region shows that the rocks are permeable enough to facilitate the infiltration of groundwater resources.

\section{Acknowledgements}

The authors are grateful to the International Foundation for Sciences (IFS) and the European Space Agency (ESA) for their financial and technical support.

\section{Conflicts of Interest}

The authors declare no conflicts of interest regarding the publication of this paper.

\section{References}

[1] Dumort, J. (1968) Carte géologique de reconnaissance du Cameroun à l'échelle du $1 / 500000$, coupure Douala-Ouest avec notice explicative. Bulletin de la direction de géologie et des mines, Cameroun.

[2] Weecksteen, G. (1957) Carte géologique de reconnaissance à l'échelle du 1/500.000 Territoire du Cameroun, Douala Est, Dir Mines Géol Cameroun, Paris, 1.

[3] Nzolang, C. (2005) Crustal Evolution of the Precambrian Basement in West Cameroon: Inference from Geochemistry, Sr-Nd Isotopes and Experimental Investigation of Some Granitoids and Metamorphic Rocks. Niigata University, Niigata, Japan.

[4] Mbianya, G.N., Ngnotue, T., Wambo, J.D.T., Ganno, S., Pour, A.B., Kenne, P.A., Fossi, D.H. and Wolf, I.D. (2021) Remote Sensing Satellite-Based Structural/Alteration Mapping for Gold Exploration in the Ketté Goldfield, Eastern Cameroon. Journal of African Earth Sciences, 184, Article ID: 104386.

https://doi.org/10.1016/j.jafrearsci.2021.104386 
[5] O’leary, D., Friedman, J. and Pohn, H. (1976) Lineament, Linear, Lineation: Some Proposed New Standards for Old Terms. Geological Society of America Bulletin, 87, 1463-1469. https://doi.org/10.1130/0016-7606(1976)87\%3C1463:LLLSPN\%3E2.0.CO;2

[6] Scanvic, J.-Y. (1994) Télédétection aérospatiale et informations géologiques. Bureau de recherches géologiques et minières, Orléans, France.

[7] Assatse, W.T., Nouck, P.N., Tabod, C.T., Akame, J.M. and Biringanine, G.N. (2016) Hydrogeological Activity of Lineaments in Yaoundé Cameroon Region Using Remote Sensing and GIS Techniques. The Egyptian Journal of Remote Sensing and Space Science, 19, 49-60. https://doi.org/10.1016/j.ejrs.2015.12.006

[8] Mandeng, E.P.B., Bidjeck, L.M.B., Wambo, J.D.T., Taku Jr, A., Betsi, T.B., Ipan, A.S., Nfada, L.T. and Dieudonné, L.B. (2018) Lithologic and Structural Mapping of the Abiete-Toko Gold District in Southern Cameroon, Using Landsat 7 ETM+/ SRTM. Comptes Rendus Geoscience, 350, 130-140.

https://doi.org/10.1016/j.crte.2017.11.003

[9] Nama, E. (2004) Lineament detection on Mount Cameroon during the 1999 Volcanic Eruptions Using Landsat ETM. International Journal of Remote Sensing, 25, 501-510. https://doi.org/10.1080/0143116031000102557

[10] Nono, A., Likeng, J., Wabo, H., Youmbi, G.T. and Biaya, S. (2009) Influence de la nature lithologique et des structures géologiques sur la qualité et la dynamique des eaux souterraines dans les hauts plateaux de l'Ouest-Cameroun. International Journal of Biological and Chemical Sciences, 3, 218-239. https://doi.org/10.4314/ijbcs.v3i2.44516

[11] Tchindjang, M., Njilah, I.K., Nziengui, M., Banga, C.R. and Menga, V.F. (2006) Caracterisation par l'imagerie satellitale de trois grandes structures d'effondrement dans les hautes terres de l'ouest Cameroun. African Journal of Science and Technology, 7, 9.

[12] Wambo, J.D.T., Ganno, S., Ngambu, A.A., Negue, E.N., Ondoa, J.M. and Nzenti, J.P. (2016) Use of Landsat 7 ETM+ Data for the Geological Structure Interpretation: Case Study of the Ngoura-Colomines Area, Eastern Cameroon. Journal of Geosciences, 4, 61-72.

[13] Keuni, N., Kenfack, J.V., Pelap, F.B. and Messe, M.R.D. (2021) Structural Analysis of Haut-Nkam Division, Central-Africa Using Remote Sensing Data and GIS Technics. The Egyptian Journal of Remote Sensing and Space Science. https://doi.org/10.1016/j.ejrs.2021.06.008

[14] Salomon, A.W., Rigobert, T., Dawaï, D., Kepnamou, A.D., Basile, D.M.G.G., Josué, H.K., Gaoussou, B. and André, S. (2021) Morphotectonic Analysis of Mboula Area in Relation with Central Cameroon Shear Zone (CCSZ) and Lithology Using Remote Sensing and Field Data. Journal of Geosciences, 9, 83-95.

https://doi.org/10.12691/jgg-9-2-5

[15] Ahmadi, H. and Kalkan, K. (2021) Mapping of Ophiolitic Complex in Logar and Surrounding Areas (SE Afghanistan) with ASTER Data. Journal of the Indian Society of Remote Sensing, 49, 1271-1284. https://doi.org/10.1007/s12524-021-01319-4

[16] Abdelouhed, F., Ahmed, A., Abdellah, A. and Mohammed, I. (2021) Lineament Mapping in the Ikniouen Area (Eastern Anti-Atlas, Morocco) Using Landsat-8 Oli and SRTM Data. Remote Sensing Applications. Society and Environment, 23, Article ID: 100606. https://doi.org/10.1016/j.rsase.2021.100606

[17] Arifin, A., Adnan, N.A. and Rasam, A.R.A. (2021). Multi-Sensor Assessment of Geological Lineament Detection. IOP Conference Series: Earth and Environmental 
Science, 767, Article ID: 012014. https://doi.org/10.1088/1755-1315/767/1/012014

[18] Enoh, M.A., Okeke, F.I. and Okeke, U.C. (2021) Automatic Lineaments Mapping and Extraction in Relationship to Natural Hydrocarbon Seepage in Ugwueme, South-Eastern Nigeria. Geodesy and Cartography, 47, 34-44.

https://doi.org/10.3846/gac.2021.12099

[19] Ghosh, S., Sivasankar, T. and Anand, G. (2021) Performance Evaluation of Multi-Parametric Synthetic Aperture Radar Data for Geological Lineament Extraction. International Journal of Remote Sensing, 42, 2574-2593. https://doi.org/10.1080/01431161.2020.1856963

[20] Shebl, A. and Csámer, Á. (2021) Reappraisal of DEMs, Radar and Optical Datasets in Lineaments Extraction with Emphasis on the Spatial Context. Remote Sensing Applications: Society and Environment, 24, Article ID: 100617. https://doi.org/10.1016/j.rsase.2021.100617

[21] Lepage, R., Rouhana, R.G., Onge, B.S., Noumeir, R. and Desjardins, R. (2000) Cellular Neural Network for Automated Detection of Geological Lineaments on Radarsat Images. IEEE Transactions on Geoscience and Remote Sensing, 38, 1224-1233. https://doi.org/10.1109/36.843014

[22] Aghaee, A., Shamsipour, P., Hood, S. and Haugaard, R. (2021) A Convolutional Neural Network for Semi-Automated Lineament Detection and Vectorisation of Remote Sensing Data Using Probabilistic Clustering: A Method and a Challenge, Computers \& Geosciences, 151, Article ID: 104724. https://doi.org/10.1016/j.cageo.2021.104724

[23] Vassilas, N., Perantonis, S., Charou, E., Tsenoglou, T., Stefouli, M. and Varoufakis, S. (2002) Delineation of Lineaments from Satellite data Based on Efficient Neural Network and Pattern Recognition Techniques. Proceedings of 2 nd Hellenic Conference on AI, Thessaloniki, 11-12 April 2002, 355-365.

[24] Olivry, J.-C. (1986) Fleuves et rivières du Cameroun. Monographies hydrologiques ORSTOM. Office of Scientific and Technical Research Overseas, Paris.

[25] Kwékam, M., Liégeois, J.-P., Njonfang, E., Affaton, P., Hartmann, G. and Tchoua, F. (2010) Nature, Origin and Significance of the Fomopéa Pan-African High-K CalcAlkaline Plutonic Complex in the Central African Fold Belt (Cameroon). Journal of African Earth Sciences, 57, 79-95. https://doi.org/10.1016/j.jafrearsci.2009.07.012

[26] Toteu, S., Van Schmus, W., Penaye, J. and Michard, A. (2001) New U-Pb and Sm-Nd Data from North-Central Cameroon and Its Bearing on the Pre-Pan African History of Central Africa. Precambrian Research, 108, 45-73. https://doi.org/10.1016/S0301-9268(00)00149-2

[27] Toteu, S.F., Penaye, J. and Djomani, Y.P. (2004) Geodynamic Evolution of the Pan-African Belt in Central Africa with Special Reference to Cameroon. Canadian Journal of Earth Sciences, 41, 73-85. https://doi.org/10.1139/e03-079

[28] Jofack Sokeng, V.-C., Kouamé, K.F., Youan Ta, M., Saley, M.B. and Kouamé, K. (2014) Extraction automatique des linéaments sur les images satellitaires par réseaux de neurones: Contribution à la cartographie structurale du socle précambrien de la région de Bondoukou (nord-est de la Côte d'Ivoire). Revue Scientifique Internationale de Géomatique, 1, 1-23.

[29] Gazi, O.B., Belal, M. and Abdel-Galil, H. (2014) Edge Detection in Satellite Image Using Cellular Neural Network. International Journal of Advanced Computer Science and Applications, 5, 61-70. https://doi.org/10.14569/IJACSA.2014.051010 
[30] Jellouli, A., El Harti, A., Adiri, Z., Chakouri, M., El Hachimi, J. and Bachaoui, E.M. (2021) Application of Optical and Radar Data for Lineaments Mapping in Kerdous Inlier of the Anti Atlas Belt, Morocco. EGU General Assembly Conference Assembly 2021, Online, 19-30 April 2021, Article ID: EGU21-7895.

https://doi.org/10.5194/egusphere-egu21-7895 